DOI https://doi.org/10.30525/978-9934-26-045-2-3

\title{
ДОСЛІДЖЕННЯ ТЕОРЕТИЧНИХ АСПЕКТІВ КОРПОРАТИВНОГО УПРАВЛІННЯ
}

\author{
Джурик Ю. А. \\ аспірант першого року навчання \\ кафедри адміністративного та фінансового менеджменту \\ Національного університету «Львівська політехніка» \\ м. Львів, Украӥна \\ комериійний директор \\ ТОВ «Торговий дім «Електрон» \\ м. Київ, Украӥна
}

\begin{abstract}
Постійне посилення глобалізаційних процесів, підвищена конкурентоспроможність сучасних компаній та необхідність якісного використання наявних ресурсів посилили цікавість до окремої системи управління - корпоративне управління. Часте неправильне трактування та недооцінка корпоративного управління приводили до великої кількості корпоративних провалів, неефективного керівництва та фінансових проблем. Тому детермінація поняття корпоративне управління на сьогодні є дуже актуальним. Питанням корпоративного управління займались видатні українські та зарубіжні дослідники, такі як В. Свтушевський Л. Довгань, Д. Баюра, Н. Румянцева, Д. Паунд, Д. Кері та інші Саме явище «корпоративне управління» 3'явилось щонайменше 3 моменту заснування у XVI-XVII століттях перших компаній у їх класичному розумінні (Ост-Індійська компанія, Компанія Гудзонової затоки). Це були перші акціонерні компанії, де тогочасний інвестор вкладав частину власних коштів разом 3 іншими співінвесторами, розділяючи з ними як можливі ризики, так і доходи. Відповідно кожен з таких інвесторів володів компанією в межах своєї частки і був її акціонером. В цей період вибрана організаційно-правова форма сприяла виникненню конфлікту інтересів між акціонерами та найнятим керівництвом. Була необхідність врегулювати проблему суперечностей аби досягнути синергії між акціонерами та тими особами, які здійснюють безпосереднє управління. Про «агентську проблему», тобто коли інтереси власника та менеджменту не збігаються, у 18 столітті згадував Адам Сміт у своїй книзі «Багатство
\end{abstract}


народів». 3 його точки зору це здавалося непереборною проблемою для ефективності корпорації. На його думку «Найняті менеджери, як основні користувачі коштів, ніколи не зможуть ставитись до них 3 такою ж обережністю, як власники (акціонери) цих коштів» [1]. На сьогоднішній день можна виділити певний ряд підходів до визначення сутності корпоративного управління, зокрема [2, с. 11]: правовий, економічний, соціальний, психологічний, із позиції компанії, із позиції акціонера тощо. Також варто зазначити, що поняття корпоративного управління зустрічається у різних джерелах, зокрема визначається, що корпоративне управління - це система, за допомогою якої спрямовуються та контролюються компанії. Виконавчі органі відповідальні за управління компаніями. Роль акціонерів у управлінні полягає у призначенні членів виконавчого органу та аудиторів [3]. В кодексі корпоративного управління Великої Британії йдеться про те, що корпоративне управління - це в першу чергу те, що робить виконавчий орган компанії і як він визначає цінності компанії, а мета корпоративного управління полягає у сприянні ефективному, підприємницькому та виваженому управлінні, що може забезпечити довгостроковий успіх компанії [4]. В Україні теж є документ, у якому міститься визначення корпоративного управління - Принципи корпоративного управління, затверджені НКЦПФР, де окрім власника та найнятого менеджменту йдеться ще й про інших зацікавлених осіб. Відповідно до цього документу, корпоративне управління являє собою систему відносин між виконавчим органом компанії, іiї спостережною радою, iї акціонерами та іншими зацікавленими особами [5]. Таке ж визначення закріплено у Принципах корпоративного управління Організації економічного співробітництва та розвитку (далі - ОЕСР). Також варто зазначити, що у 2015 році ОЕСР було розроблено Керівні принципи корпоративного врядування на підприємствах державної форми власності, які містять рекомендації органам державного управління щодо забезпечення ефективного, прозорого та відповідального функціонування підприємств державної форми власності (ДП). [6]. Виходячи 3 наведених дефініцій можна виокремити певні ознаки, а саме, що це певна система відносин між акціонерами, виконавчим органом та іншими зацікавленими особами; здійснення ефективного управління, яке має бути направленим на досягнення стратегічних цілей компанії; призначення виконавчого органу. Спираючись на вищенаведені поняття та ознаки, можна визначити 
корпоративне управління як певну систему управління, за якої виконавчий орган сприяє ефективному розвитку компанії, знаходячи підтримку у акціонерів та інших зацікавлених осіб, які спільно діють заради успішного майбутнього компанії. Основними завданнями корпоративного управління вважаються: створення i забезпечення діяльності ефективного механізму аналізу, який полягає у стратегічному управлінні, прийнятті управлінських рішень і контролі за діяльністю товариства; забезпечення однакового i справедливого ставлення до усіх акціонерів і можливостей усім акціонерам скористатися ефективними способами захисту у разі порушення їхніх прав; створення балансу інтересів зацікавлених осіб - акціонерів, менеджерів, працівників, замовників, партнерів, постачальників і кредиторів акціонерного товариства, держави і громадськості [7]. Що стосується основних принципів корпоративного управління, то їх поява була зумовлена наступними чинниками: спочатку у США, а потім i y Сполученому Королівстві були виявлені неодноразові випадки приховування інформації про реальний фінансовий стан публічних компаній зі сторони виконавчих органів; аудитори, що наймалися публічними компаніями i які відповідали за перевірку фінансової звітності, виявилися неспроможними виявити порушення з боку таких компаній, а часто навіть прикривали їх; фінансові ринки сколихнув ряд гучних скандалів, що значно похитнули довіру інвесторів до публічних компаній та фондових бірж. У XX столітті було створено перші документи, які закріплювали основні принципи управління. В Сполученому Королівстві було створено Cadbury Committee, який підготував Code of Best Practice. Кодекс найкращої практики (the Code of Best Practice) був розроблений ще у 1992 році, оскільки ця подія відбулась 28 років тому назад, то на даний час діє Кодекс корпоративного управління Сполученого Королівства (the UK Corporate Governance Code) [4]. Цей Кодекс складається 3 п’яти секцій. Наприкінці ж 2016 року було дано старт новій реформі корпоративного управління (Green Paper). Стосується вона трьох основних аспектів. Це виконавча винагорода; посилення голосів; а також стосується корпоративного управління у великих приватних компаніях [8]. В той же час, основним міжнародним стандартом $є$ Принципи корпоративного управління ОЕСР, які охоплюють п'ять галузей корпоративного управління: права акціонерів; рівноправність акціонерів; роль зацікавлених осіб; розкриття інформації та прозорість; обов'язки 
Ради. Що ж стосується українського підходу, то указом Президента України «Про заходи щодо розвитку корпоративного управління в акціонерних товариствах» від 21 березня 2002 року було постановлено завдання ДКЦПФР забезпечити розроблення та запровадження національних принципів (кодексу) корпоративного управління в акціонерних товариствах [9]. Зараз же діють Принципи корпоративного управління, затверджені рішенням НКЦПФР від 22 липня 2014 року. Принципи корпоративного управління (2014 року) складаються 3 шести розділів, а кожен з принципів містить відповідні рекомендації для здійснення якісного управління, що, в свою чергу, повинно привести до збільшення конкурентоспроможності та досягнення усіх стратегічних цілей компанії.

\section{Література:}

1. Jelena Jovanovic, Biljana Grujic. Historical development of corporate governance as the basis for current corporate trends. Journal Ekonomika, Vol. 62. № 1. P. 187-197. URL: https://pdfs.semanticscholar.org/ae2e/ ea977ebd1fccbffda37274f177ccf496dd07.pdf (дата звернення 27.11.2020)

2. Сергійчук C.I. Корпоративне управління: навчальний посібник / C.I. Сергійчук - Миколаїв: НУК, 2016. 228 с. URL: https:// sergiychuk.bplan.com.ua/science/3-04.pdf (дата звернення 27.11.2020)

3. Report of the Committee on the Financial Aspects of Corporate Governance and Gee and Co. Ltd. The financial aspects of corporate governance of 1 December 1992. URL: https://ecgi.global/sites/default/ files//codes/documents/cadbury.pdf (дата звернення 27.11.2020)

4. The UK Corporate Governance Code (April 2016). Financial Reporting Council. URL: https://www.frc.org.uk/getattachment/ca7e94c4b9a9-49e2-a824-ad76a322873c/UK-Corporate-Governance-Code-April2016.pdf/ (дата звернення 27.11.2020)

5. Про затвердження Принципів корпоративного управління: Рішення Національної комісії з цінних паперів та фондового ринку від 22.07.2014 p. № 955. URL: https://www.nssmc.gov.ua/documents/ rshennya-pro-zatverdzhennya-printsipv-korporativnogo-upravlnnya/ (дата звернення 27.11.2020)

6. Керівні принципи ОЕСР щодо корпоративного врядування на підприємствах державної форми власності. Редакція 2015 року. URL: https://www.oecd-ilibrary.org/docserver/9789264312906-uk.pdf? expires $=1606498070 \& \mathrm{id}=\mathrm{id} \&$ accname $=$ guest $\&$ checksum $=9 \mathrm{BCA66A0351D}$ A12786C2A36A5D7FC080\&fbclid=IwAR2- 
cIbgcIi5cAaPCqiQqRwQHJk11FSGLjFHIHgth1wQqc17NHzDR_jAXRs (дата звернення 27.11.2020)

7. Харун О.А. Розвиток корпоративного управління в умовах глобалізації. Східна Європа: Економіка, Бізнес та Управління. 2018. Випуск 6 (17). C. 409-415. URL: https://chmnu.edu.ua/wpcontent/uploads/2019/07/Harun-O.А..pdf (дата звернення 27.11.2020)

8. OECD Principles of Corporate Governance. OECD 2004. URL: https://www.oecd.org/corporate/ca/corporategovernanceprinciples/315 57724.pdf (дата звернення 27.11.2020)

9. Про заходи щодо розвитку корпоративного управління в акціонерних товариствах: Указ Президента України від 21.03.2002 p. № 280/2002. URL: https://zakon.rada.gov.ua/laws/show/280/2002\#Text (дата звернення 27.11.2020)

DOI https://doi.org/10.30525/978-9934-26-045-2-4

\title{
A SURVEY RESEARCH METHOD AS A TOOL TO GRASP FISCAL DECENTRALIZATION IN UKRAINE
}

\author{
Kovalchuk A. V. \\ Ph.D. Student at School of Economics \\ Shandong University \\ Shandong, China
}

To date, fiscal decentralization (FD) has been advocated throughout the world. Examples are prevalent around the world: functional devolution, decentralization of fiscal decision-making and public administration, and socioeconomic reforms (from centralized to decentralized economies) in Asian and Eastern European countries. In Ukraine at the same was launched about seven years ago.

The circumstantial evidence is that FD is suggested to improve the performance of the public sector; the common evidence is that FD is considered to have the potential to foster economic development and institutional advancement. However, numerous studies adhere to the conventional argument that FD may raise economic efficiency in the public sector has a possibility not to be suitable in developing countries. Moreover, 